IZA DP No. 7353

Subjective Well-Being and Income:

Is There Any Evidence of Satiation?

Betsey Stevenson

Justin Wolfers

April 2013 


\title{
Subjective Well-Being and Income: Is There Any Evidence of Satiation?
}

\author{
Betsey Stevenson \\ University of Michigan, \\ CESifo and NBER \\ Justin Wolfers \\ University of Michigan, \\ CESifo, CEPR, IZA and NBER
}

Discussion Paper No. 7353

April 2013

IZA

P.O. Box 7240

53072 Bonn

Germany

Phone: +49-228-3894-0

Fax: +49-228-3894-180

E-mail: iza@iza.org

\begin{abstract}
Any opinions expressed here are those of the author(s) and not those of IZA. Research published in this series may include views on policy, but the institute itself takes no institutional policy positions. The IZA research network is committed to the IZA Guiding Principles of Research Integrity.

The Institute for the Study of Labor (IZA) in Bonn is a local and virtual international research center and a place of communication between science, politics and business. IZA is an independent nonprofit organization supported by Deutsche Post Foundation. The center is associated with the University of Bonn and offers a stimulating research environment through its international network, workshops and conferences, data service, project support, research visits and doctoral program. IZA engages in (i) original and internationally competitive research in all fields of labor economics, (ii) development of policy concepts, and (iii) dissemination of research results and concepts to the interested public.
\end{abstract}

IZA Discussion Papers often represent preliminary work and are circulated to encourage discussion. Citation of such a paper should account for its provisional character. A revised version may be available directly from the author. 
IZA Discussion Paper No. 7353

April 2013

\section{ABSTRACT}

\section{Subjective Well-Being and Income: Is There Any Evidence of Satiation?*}

Many scholars have argued that once "basic needs" have been met, higher income is no longer associated with higher in subjective well-being. We assess the validity of this claim in comparisons of both rich and poor countries, and also of rich and poor people within a country. Analyzing multiple datasets, multiple definitions of "basic needs" and multiple questions about well-being, we find no support for this claim. The relationship between wellbeing and income is roughly linear-log and does not diminish as incomes rise. If there is a satiation point, we are yet to reach it.

JEL Classification: D6, I3, N3, O1, O4

Keywords: $\quad$ subjective well-being, happiness, satiation, basic needs, Easterlin paradox

Corresponding author:

Justin Wolfers

University of Michigan

Weill Hall

735 South State Street

Ann Arbor, MI 48109-3091

USA

E-mail: jwolfers@umich.edu

\footnotetext{
* A shorter version of this paper will appear in the American Economic Review, Papers and Proceedings in May 2013. The authors wish to thank Angus Deaton, Daniel Kahneman, and Alan Krueger for useful discussions and The Gallup Organization, where Wolfers serves as a Senior Scientist, for providing data. The views expressed herein are those of the author(s) and do not necessarily reflect the views of the National Bureau of Economic Research.
} 
In 1974 Richard Easterlin famously posited that increasing average income did not raise average well-being, a claim that became known as the Easterlin Paradox. However, in recent years new and more comprehensive data has allowed for greater testing of Easterlin's claim. Studies by us and others have pointed to a robust positive relationship between well-being and income across countries and over time (Deaton, 2008; Stevenson and Wolfers, 2008; Sacks, Stevenson, and Wolfers, 2013). Yet, some researchers have argued for a modified version of Easterlin’s hypothesis, acknowledging the existence of a link between income and well-being among those whose basic needs have not been met, but claiming that beyond a certain income threshold, further income is unrelated to well-being.

The existence of such a satiation point is claimed widely, although there has been no formal statistical evidence presented to support this view. For example Diener and Seligman (2004, p.5) state that "there are only small increases in well-being” above some threshold. While Clark, Frijters and Shields (2008, p.123) state more starkly that "greater economic prosperity at some point ceases to buy more happiness,” a similar claim is made by Di Tella and MacCulloch (2008, p.17): “once basic needs have been satisfied, there is full adaptation to further economic growth.” The income level beyond which further income no longer yields greater well-being is typically said to be somewhere between $\$ 8,000$ and $\$ 25,000$. Layard (2003, p.17) argues that “once a country has over $\$ 15,000$ per head, its level of happiness appears to be independent of its income;” while in subsequent work he argued for a \$20,000 threshold (Layard, 2005 p.32-33). Frey and Stutzer (2002, p.416) claim that “income provides happiness at low levels of development but once a threshold (around \$10,000) is reached, the average income level in a country has little effect on average subjective well-being.” 
Many of these claims, of a critical level of GDP beyond which happiness and GDP are no longer linked, come from cursorily examining plots of well-being against the level of per capita GDP. Such graphs show clearly that increasing income yields diminishing marginal gains in subjective well-being. ${ }^{2}$ However this relationship need not reach a point of nirvana beyond which further gains in well-being are absent. For instance Deaton (2008) and Stevenson and Wolfers (2008) find that the well-being-income relationship is roughly a linear-log relationship, such that, while each additional dollar of income yields a greater increment to measured happiness for the poor than for the rich, there is no satiation point.

In this paper we provide a sustained examination of whether there is a critical income level beyond which the well-being-income relationship is qualitatively different, a claim referred to as the modified-Easterlin hypothesis. ${ }^{3}$ As a statistical claim, we shall test two versions of the hypothesis. The first, a stronger version, is that beyond some level of basic needs, income is uncorrelated with subjective well-being; the second, a weaker version, is that the well-beingincome link estimated among the poor differs from that found among the rich.

Claims of satiation have been made for comparisons between rich and poor people within a country, comparisons between rich and poor countries, and comparisons of average well-being in countries over time, as they grow. The time series analysis is complicated by the challenges of compiling comparable data over time and thus we focus in this short paper on the cross-sectional relationships seen within and between countries. Recent work by Sacks, Stevenson, and Wolfers

\footnotetext{
${ }^{2}$ We should add a caveat, that this inference of "diminishing marginal well-being” requires taking a stronger stand on the appropriate cardinalization of subjective well-being (Oswald, 2008).

${ }^{3}$ We should note that the term "modified-Easterlin hypothesis" is something of a misnomer, as Easterlin himself is not among those claiming a satiation point. Instead, Easterlin and Sawangfa (2009) make the even stronger claim rising aggregate income is not associated with rising subjective well-being at any level of income. While incorrect, it is not uncommon, however, to attribute the "modified Eaterlin hypothesis" to Easterlin, and indeed, his citation for the IZA Prize says that: "Societies with higher material wealth are on average more satisfied than poorer ones, but once the participation in the workforce ensures a certain level of material wealth, guaranteeing basic needs, individual as well as societal well-being as a whole are no longer increasing with a growth of economic wealth.”
} 
(2013) provide evidence on the time series relationship that is consistent with the findings presented here.

To preview, we find no evidence of a satiation point. The income-well-being link that one finds when examining only the poor, is similar to that found when examining only the rich. We show that this finding is robust across a variety of datasets, for various measures of subjective well-being, at various thresholds, and that it holds in roughly equal measure when making cross-national comparisons between rich and poor countries as when making comparisons between rich and poor people within a country.

\section{Cross-Country Comparisons}

We begin by evaluating whether countries at different levels of economic development have different average levels of subjective well-being. Our measure of economic development is the log of real GDP per capita, measured at purchasing power parity. ${ }^{4}$ We will follow four approaches in our analysis: following Layard (2003), we will define "rich" as those people or countries with income greater than $\$ 15,000$ per capita; alternatively, following Di Tella and MacCulloch, we will contrast the income-happiness gradient in each half of the income distribution (with the median income "cutpoint” estimated separately, depending on the specific population we are studying). We will also consider lower and higher cut-points of $\$ 8,000$ and $\$ 25,000$. Finally—and perhaps more satisfyingly—we will, where possible, show scatter plots and non-parametric fits of the income-happiness data over the full range of variation, allowing the reader to assess visually if this relationship changes beyond any particular income level.

\footnotetext{
${ }^{4}$ For most countries GDP comes from the World Bank's World Development Indicators. Detailed information about how we fill in missing data is available in Sacks, Stevenson, and Wolfers (2013).
} 
We want to assess well-being measured in many different data sets, thus we standardize well-being responses by subtracting the mean, and dividing by the typical cross-section of happiness within a country at a point in time. ${ }^{5}$ This approach yields "z-score" measures of wellbeing that are transparent, easy to calculate, and comparable across data sets measuring wellbeing on differing scales. It also ensures the estimated well-being-income gradient is roughly comparable to earlier research which had analyzed ordered probit regressions. However, the disadvantage of this approach is that it is clearly ad hoc, as it assumes, for instance, that the difference between being "very happy" and "pretty happy” is equivalent to the difference between "pretty happy” and "not too happy."6

Figure 1 shows two measures of life satisfaction drawn from the Gallup World Poll: in the top panel, we analyze responses to the "ladder of life" question, while the bottom panel shows responses to a question about overall life satisfaction. ${ }^{7}$ The data are drawn from the five waves of the Gallup World Poll run between 2008 and 2012 and GDP per capita, plotted on a log scale. We have data on 155 countries, which account for over 95\% of the world's population, across the spectrum of levels of economic development. Each of these measures of subjective well-being is highly correlation with GDP per capita ( $\rho=0.79$ for the 155 countries in the upper

\footnotetext{
5 That is, the denominator in this "z-score" is the standard deviation of well-being after controlling for country and wave fixed effects.

${ }^{6}$ Fortunately, this issue turns out to be more troubling in theory than in practice; Stevenson and Wolfers (2008) show alternative approaches using instead ordered probits or logits yield estimates of national happiness averages that are highly correlated $(\rho>0.99)$.

${ }^{7}$ The question analyzed in the top graph is "Please imagine a ladder with steps numbered from zero at the bottom to ten at the top. Suppose we say that the top of the ladder represents the best possible life for you, and the bottom of the ladder represents the worst possible life for you. On which step of the ladder would you say you personally feel you stand at this time, assuming that the higher the step the better you feel about your life, and the lower the step the worse you feel about it? Which step comes closest to the way you feel?” The question answered in the bottom graph is "All things considered, how satisfied are you with your life as a whole these days? Use a 0 to 10 scale, where 0 is dissatisfied and 10 is satisfied."
} 
panel, and 0.85 for the 86 countries in the lower panel). The solid lines show the results from a simple OLS regression, estimated for the full sample:

$$
\text { Well- } \text { being }_{c}=\alpha+\beta \log \left(G D P_{c}\right)+\epsilon_{c}
$$

The estimated well-being-income gradient $(\beta)$ is $0.33(\mathrm{se}=0.02)$ for the ladder question and 0.44 $(\mathrm{se}=0.03)$ for the life satisfaction question. The figure also plots a local linear regression as a dotted line, which allows for a non-parametric fit of the well-being-income relationship. If there were a "satiation point," this non-parametric fit would flatten out once basic needs were met. Instead, the line steepens slightly among the rich nations in both graphs. Indeed, the most striking finding is simply how closely the non-parametric fit lies to the OLS regression line. That is, the well-being-income relationship among poor nations appears to extend roughly equally among rich nations. ${ }^{8}$ We repeat this exercise for using data from the World Values Survey for both life satisfaction (Appendix Figure A1) and happiness (Figure A2), as well as for the satisfaction ladder question asked in the Pew Global Attitudes Survey (Figure A3), and the 4point happiness question asked in the International Social Survey Program (Figure A4). In each case, we find qualitatively similar results.

\footnotetext{
8 Deaton (2008) and Stevenson and Wolfers (2008) make similar arguments using 2006 data from the Gallup World Poll.
} 
Figure 1: Satisfaction and GDP per capita
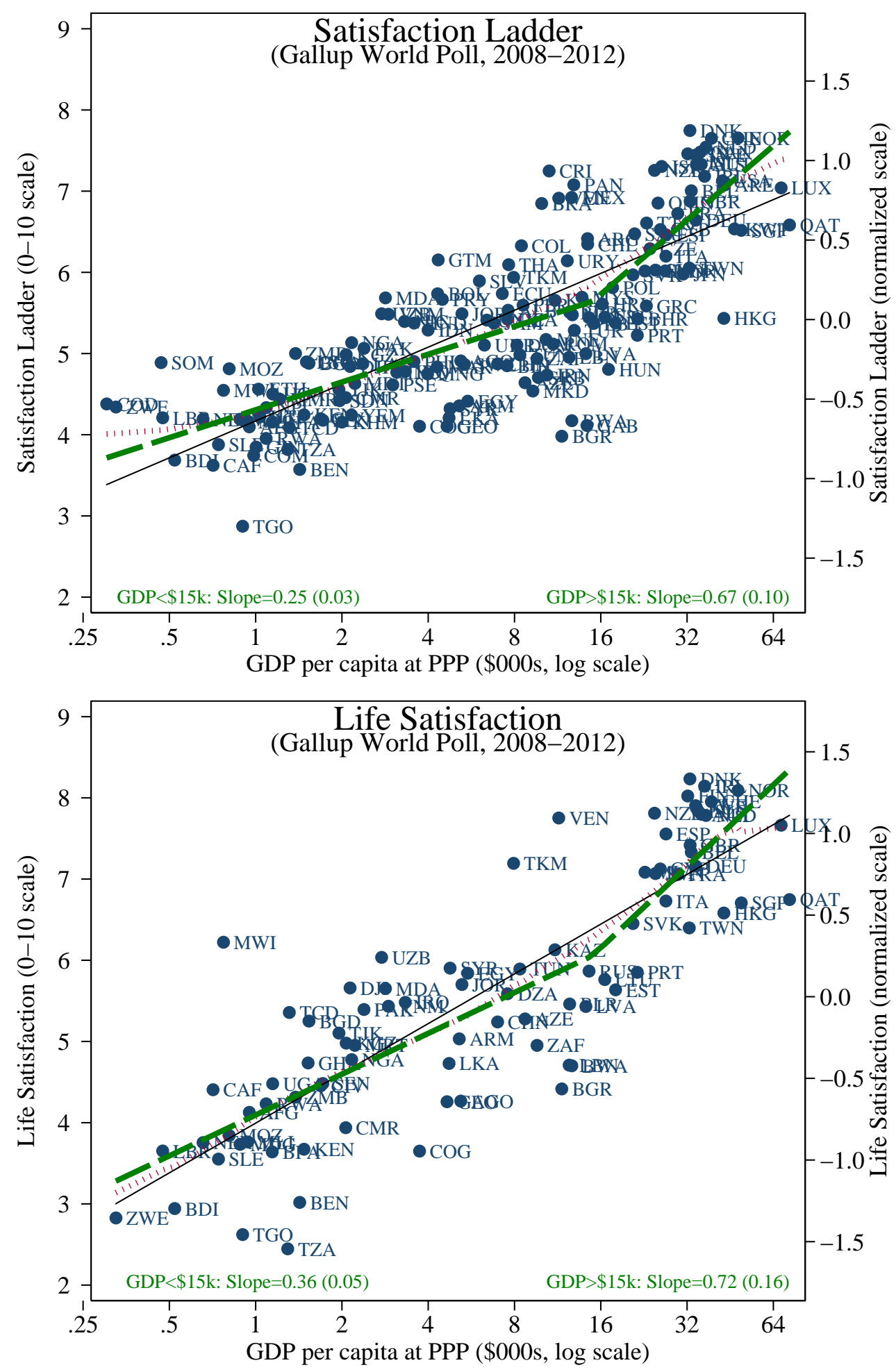

Note: Author's calculations, based on 2008-2012 waves of the Gallup World Poll. Solid line shows results from a simple OLS regression of satisfaction on log GDP per capita; the dashed line allow the slope to shift at a per capita GDP of $\$ 15,000$, respectively. The dotted line shows a lowess fit with bandwidth set to 0.8 . 
Our more formal tests of the modified-Easterlin hypothesis come from regressions of the form:

$$
\begin{aligned}
{\text { Well- } \text { being }_{c}=\alpha} & +\beta_{\text {poor }} I\left(G D P_{c}<k\right) \times\left(\log \left(G D P_{c}\right)-\log (k)\right) \\
& +\beta_{\text {rich }} I\left(G D P_{c} \geq k\right) \times\left(\log \left(G D P_{c}\right)-\log (k)\right)+\epsilon_{c}
\end{aligned}
$$

where the subscript $c$ denotes country, the independent variables are the interaction of log real GDP per capita with a dummy variable indicating whether GDP per capita is above or below a cut-off level, $\$ k$. The coefficient $\beta_{\text {poor }}$ is the well-being-income gradient among "poor” countries (those with GDP $<\$ \mathrm{k}$ ), and $\beta_{\text {rich }}$ is the gradient among "rich" countries (those with GDP $\geq \$ k)$. By measuring $\log (G D P)$ relative to a “cutoff,” this functional form allows for a change in the well-being-income gradient (i.e., a "kink" in the regression line) once GDP per capita exceeds the cutoff, but it rules out a discontinuous shift in well-being once per capita GDP exceeds $\$ k{ }^{9}$ This specification allows us to test both the "strong” version of the modifiedEasterlin hypothesis, which posits that $\beta_{\text {rich }}=0$, and the "weak" version, suggesting $\beta_{\text {poor }}>$ $\beta_{\text {rich }}$

In Table 1 we report results where the cutoff level of per capita GDP, $\$ k$, is set to $\$ 15,000 .{ }^{10}$ We repeat the results seen in Figure 1 in the first row. Subsequent rows show the results across different questions assessing well-being and different datasets. The well-beingincome gradient in the Gallup World Poll clearly remains strong for the rich countries, and indeed, is somewhat stronger among countries whose per capita GDP exceeds $\$ 15,000$. These data clearly reject both the weak and strong versions of the modified-Easterlin hypothesis.

\footnotetext{
${ }^{9}$ We obtain similar results if instead we estimate the well-being-income gradient separately for rich and poor countries.

${ }^{10}$ Stevenson and Wolfers (2008) show estimates of ordered probit regressions estimating the well-being income gradient for incomes above and below $\$ 15,000$, while Deaton (2008) tested thresholds of $\$ 12,000$ and $\$ 20,000$. Table 2 shows the results using alternative thresholds of $\$ 8,000$ and $\$ 25,000$, as well as the median level of GDP for the sample.
} 


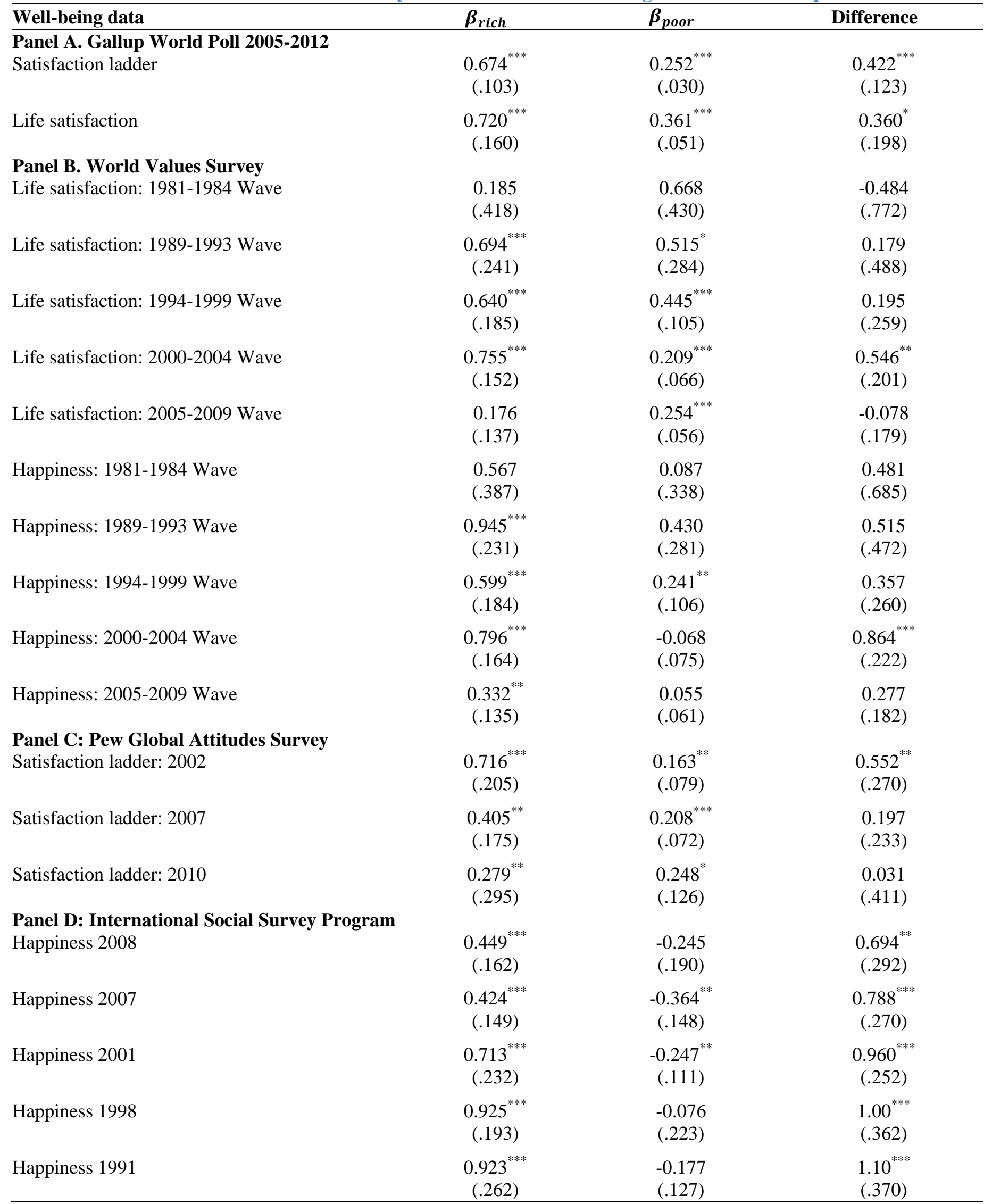

Notes: ${ }^{* * *},{ }^{* *}$, and ${ }^{*}$ denote statistically significantly different from zero at $1 \%, 5 \%$ and $10 \%$ levels, respectively. 
The next ten rows repeat the analysis using five rounds of the World Values Survey for both a life satisfaction question which mirrors that in the Gallup World Poll, and a question on happiness. The results roughly parallel those above, albeit with less statistical power. ${ }^{11}$

In seven of the ten rows we can reject the strong claim that $\beta_{\text {rich }}=0$. In two cases $\beta_{\text {rich }}$ and $\beta_{\text {poor }}$ are statistically significantly different from each other, however the well-beingincome relationship is steeper among rich countries than the poor. Indeed, in all but two cases, the estimate of $\beta_{\text {rich }}$ actually exceeds that for $\beta_{\text {poor }}$ (rather than the other way around). In the two cases in which the point estimate of $\beta_{\text {poor }}$ is larger, we cannot reject the null that $\beta_{\text {rich }}=$ $\beta_{\text {poor }}$.

There are two other useful cross-country studies that are worth analyzing, the Pew Global Attitudes studies, which posed the satisfaction ladder question in 44 countries in 2002, 47 countries in 2007, and 22 countries in 2010, and the International Social Survey Program, which asked a consistent happiness question in 1991, 1998, 2001, 2007 and 2008 (plotted in Appendix Figures A3 and A4). Each of these datasets strongly reject the null that $\beta_{\text {rich }}=0$. Moreover, to the extent that the well-being-income relationship changes, it appears stronger for rich countries. Somewhat paradoxically, the ISSP data appear to show a negative well-being-income gradient among poor nations, but this is entirely due to a single influential observation, the Philippines (whose influence is even greater given that these samples contain mostly medium- and highincome countries).

In Table 2 we consider alternative thresholds for "poor" and "rich”. In the first three columns we consider differences between below and above median income countries. In the next

\footnotetext{
${ }^{11}$ In several countries the surveys were not nationally representative, focusing instead on urban areas and more educated members of society. Our anaylsis drops highly unrepresentative observations as detailed in Stevenson and Wolfers (2008) and Sacks, Stevenson, and Wolfers (2013).
} 
three we use an $\$ 8,000$ threshold such that poor countries are those with GDP per capita below $\$ 8,000$. Finally, in the last three columns we consider a higher income threshold of $\$ 25,000$. In these alternative specifications, most of the estimates of $\beta_{\text {rich }}$ are statistically significantly different from zero and we remain unable to reject the null that $\beta_{\text {rich }}=\beta_{\text {poor }}$ in most of our samples. For the estimates in which $\beta_{\text {rich }}$ and $\beta_{\text {poor }}$ are statistically significantly different from each other, in all but one case the estimate of $\beta_{\text {rich }}$ exceeds that for $\beta_{\text {poor }}$.

In sum, comparisons of average levels of subjective well-being and GDP per capita across countries suggest that the well-being-income relationship observed among poor countries holds in at least equal measure among rich countries. In the few cases where we cannot reject $\beta_{\text {rich }}=$ 0 , we also cannot reject $\beta_{\text {rich }}=\beta_{\text {poor }}$. Our larger datasets emphatically reject the weak and strong forms of the modified-Easterlin hypothesis, while the smaller samples are sufficiently imprecise as to provide no statistically significant evidence in support of (or against) it. 
Threshold: Median Income

Threshold: $\$ 8,000$

Threshold: $\$ 25,000$

\begin{tabular}{|c|c|c|c|c|c|c|c|c|c|}
\hline Well-being data & $\boldsymbol{\beta}_{\text {rich }}$ & $\beta_{\text {poor }}$ & Difference & $\beta_{\text {rich }}$ & $\boldsymbol{\beta}_{\text {poor }}$ & Difference & $\boldsymbol{\beta}_{\text {rich }}$ & $\boldsymbol{\beta}_{\text {poor }}$ & Difference \\
\hline \multicolumn{10}{|c|}{ Panel A. Gallup World Poll 2005-2012 } \\
\hline Satisfaction ladder & $\begin{array}{c}0.510^{*+* *} \\
(.052)\end{array}$ & $\begin{array}{c}0.219^{*+* *} \\
(.036)\end{array}$ & $\begin{array}{c}0.291^{* * * *} \\
(.080)\end{array}$ & $\begin{array}{c}0.518^{* * * *} \\
(.054)\end{array}$ & $\begin{array}{c}0.221^{* * * *} \\
(.035)\end{array}$ & $\begin{array}{c}0.296^{* * * *} \\
(.081)\end{array}$ & $\begin{array}{c}0.774^{* * * *} \\
(.204)\end{array}$ & $\begin{array}{c}0.298^{* * * *} \\
(.024)\end{array}$ & $\begin{array}{l}0.475^{* *} \\
(.217)\end{array}$ \\
\hline Life satisfaction & $\begin{array}{l}0.552^{* * *} \\
(.072)\end{array}$ & $\begin{array}{l}0.337^{* * * *} \\
(.070)\end{array}$ & $\begin{array}{l}0.215 \\
(.131)\end{array}$ & $\begin{array}{l}0.583^{* * *} \\
(.088)\end{array}$ & $\begin{array}{c}0.344^{* * *} \\
(.065)\end{array}$ & $\begin{array}{l}0.239^{*} \\
(.142)\end{array}$ & $\begin{array}{l}0.601^{* *} \\
(.265)\end{array}$ & $\begin{array}{l}0.423^{*+* * *} \\
(.038)\end{array}$ & $\begin{array}{l}0.117 \\
(.288)\end{array}$ \\
\hline \multicolumn{10}{|l|}{ Panel B. World Values Survey } \\
\hline Life satisfaction: 1981-1984 & $\begin{array}{c}0.64 \\
(.552)\end{array}$ & $\begin{array}{l}0.431 \\
(.303)\end{array}$ & $\begin{array}{l}0.209 \\
(.773)\end{array}$ & $\begin{array}{c}0.19 \\
(.176)\end{array}$ & $\begin{array}{l}3.11^{* * *} \\
(.605)\end{array}$ & $\begin{array}{l}2.92^{* * *} \\
(.773)\end{array}$ & $\begin{array}{l}0.705 \\
(1.80)\end{array}$ & $\begin{array}{l}0.459^{*} \\
(.232)\end{array}$ & $\begin{array}{l}0.247 \\
(1.98)\end{array}$ \\
\hline Life satisfaction: 1989-1993 & $\begin{array}{l}0.636^{* * *} \\
(.323)\end{array}$ & $\begin{array}{c}0.591^{* * * *} \\
(.209)\end{array}$ & $\begin{array}{l}0.045 \\
(.495)\end{array}$ & $\begin{array}{l}0.647^{*+* *} \\
(.107)\end{array}$ & $\begin{array}{l}-0.013 \\
(.833)\end{array}$ & $\begin{array}{c}0.66 \\
(.871)\end{array}$ & $\begin{array}{l}0.663 \\
(.419)\end{array}$ & $\begin{array}{l}0.601^{*+* * *} \\
(.115)\end{array}$ & $\begin{array}{l}0.062 \\
(.477)\end{array}$ \\
\hline Life satisfaction: 1994-1999 & $\begin{array}{l}0.565^{* * * *} \\
(.124)\end{array}$ & $\begin{array}{c}0.425^{* * * *} \\
(.114)\end{array}$ & $\begin{array}{l}0.140 \\
(.236)\end{array}$ & $\begin{array}{l}0.564^{*+* * *} \\
(.119)\end{array}$ & $\begin{array}{l}0.408^{* * *} \\
(.159)\end{array}$ & $\begin{array}{l}0.156 \\
(.246)\end{array}$ & $\begin{array}{l}0.484 \\
(.340)\end{array}$ & $\begin{array}{l}0.495^{\text {*n+* }} \\
(.078)\end{array}$ & $\begin{array}{l}0.011 \\
(.387)\end{array}$ \\
\hline Life satisfaction: 2000-2004 & $\begin{array}{l}0.641^{*+* * *} \\
(.098)\end{array}$ & $\begin{array}{l}0.164^{* * *} \\
(.078)\end{array}$ & $\begin{array}{l}0.478^{* * * *} \\
(.159)\end{array}$ & $\begin{array}{c}0.603^{* * *} \\
(.073)\end{array}$ & $\begin{array}{l}0.111 \\
(.089)\end{array}$ & $\begin{array}{l}0.492^{*+* * *} \\
(.143)\end{array}$ & $\begin{array}{c}0.745^{* * *} \\
(.276)\end{array}$ & $\begin{array}{c}0.301^{* * *} \\
(.047)\end{array}$ & $\begin{array}{l}0.444 \\
(.302)\end{array}$ \\
\hline Life satisfaction: 2005-2009 & $\begin{array}{c}0.190^{*} \\
(0.102)\end{array}$ & $\begin{array}{c}0.259^{* * *} \\
(.062)\end{array}$ & $\begin{array}{l}-0.069 \\
(.151)\end{array}$ & $\begin{array}{l}0.195^{* * *} \\
(.085)\end{array}$ & $\begin{array}{l}0.270^{* * * *} \\
(.071)\end{array}$ & $\begin{array}{l}-0.076 \\
(.142)\end{array}$ & $\begin{array}{l}0.229 \\
(.244)\end{array}$ & $\begin{array}{l}0.234^{*+* * *} \\
(.041)\end{array}$ & $\begin{array}{l}-0.005 \\
(.267)\end{array}$ \\
\hline Happiness: 1981-1984 & $\begin{array}{l}0.732 \\
(.557)\end{array}$ & $\begin{array}{l}0.280 \\
(.177)\end{array}$ & $\begin{array}{l}0.451 \\
(.656)\end{array}$ & $\begin{array}{c}0.350^{+* 4 *} \\
(.131)\end{array}$ & N.A. & N.A. & $\begin{array}{l}-0.874 \\
(1.50)\end{array}$ & $\begin{array}{l}0.367^{* * *} \\
(.150)\end{array}$ & $\begin{array}{l}-1.24 \\
(1.61)\end{array}$ \\
\hline Happiness: 1989-1993 & $\begin{array}{l}0.849^{* *} \\
(.346)\end{array}$ & $\begin{array}{l}0.615^{* * * *} \\
(.229)\end{array}$ & $\begin{array}{l}0.233 \\
(.539)\end{array}$ & $\begin{array}{c}0.740^{*+* * *} \\
(.141)\end{array}$ & $\begin{array}{l}0.028 \\
(.966)\end{array}$ & $\begin{array}{l}0.768 \\
(1.06)\end{array}$ & $\begin{array}{l}0.408 \\
(.308)\end{array}$ & $\begin{array}{l}0.716 \\
(.124)\end{array}$ & $\begin{array}{l}-0.308 \\
(.389)\end{array}$ \\
\hline Happiness: 1994-1999 & $\begin{array}{c}0.444^{*+* *} \\
(.116)\end{array}$ & $\begin{array}{l}0.221 \\
(.145)\end{array}$ & $\begin{array}{c}0.223 \\
(0.229)\end{array}$ & $\begin{array}{c}0.441^{*+* *} \\
(.103)\end{array}$ & $\begin{array}{l}0.194 \\
(.154)\end{array}$ & $\begin{array}{l}0.247 \\
(.223)\end{array}$ & $\begin{array}{l}0.558 \\
(.359)\end{array}$ & $\begin{array}{c}0.317^{*+* *} \\
(.079)\end{array}$ & $\begin{array}{l}0.241 \\
(.405)\end{array}$ \\
\hline Happiness: 2000-2004 & $\begin{array}{l}0.574^{*+*+*} \\
(.104)\end{array}$ & $\begin{array}{l}-0.117 \\
(.090)\end{array}$ & $\begin{array}{c}0.691^{* * * *} \\
(.177)\end{array}$ & $\begin{array}{c}0.499^{* * * *} \\
(.079)\end{array}$ & $\begin{array}{l}-0.177 \\
(.105)\end{array}$ & $\begin{array}{c}0.676^{* * * *} \\
(.167)\end{array}$ & $\begin{array}{l}1.04^{* *} \\
(.404)\end{array}$ & $\begin{array}{l}0.061 \\
(.055)\end{array}$ & $\begin{array}{l}0.977^{* * *} \\
(.432)\end{array}$ \\
\hline Happiness: 2005-2009 & $\begin{array}{c}0.276^{* * * *} \\
(.097)\end{array}$ & $\begin{array}{l}0.041 \\
(.066)\end{array}$ & $\begin{array}{c}0.235 \\
(0.149)\end{array}$ & $\begin{array}{c}0.244^{*+* * *} \\
(.078)\end{array}$ & $\begin{array}{l}0.019 \\
(.074)\end{array}$ & $\begin{array}{l}0.225^{*} \\
(.136)\end{array}$ & $\begin{array}{l}0.554^{* * *} \\
(.238)\end{array}$ & $\begin{array}{l}0.084 \\
(.044)\end{array}$ & $\begin{array}{l}0.470^{*} \\
(.265)\end{array}$ \\
\hline \multicolumn{10}{|c|}{ Panel C: Pew Global Attitudes Survey } \\
\hline Satisfaction ladder: 2002 & $\begin{array}{c}0.546^{* *+*} \\
(.122)\end{array}$ & $\begin{array}{l}0.119 \\
(.096)\end{array}$ & $\begin{array}{l}0.427^{* * *} \\
(.201)\end{array}$ & $\begin{array}{c}0.523^{* * *} \\
(.117)\end{array}$ & $\begin{array}{l}0.107 \\
(.104)\end{array}$ & $\begin{array}{l}0.417^{* * *} \\
(.205)\end{array}$ & $\begin{array}{l}1.38^{+* *+*} \\
(.488)\end{array}$ & $\begin{array}{l}0.202^{* * * *} \\
(.061)\end{array}$ & $\begin{array}{l}1.18^{* *} \\
(.534)\end{array}$ \\
\hline Satisfaction ladder: 2007 & $\begin{array}{l}0.378^{* * *} \\
(.148)\end{array}$ & $\begin{array}{l}0.203^{* *} \\
(.079)\end{array}$ & $\begin{array}{l}0.175 \\
(.214)\end{array}$ & $\begin{array}{c}0.362^{*+* *} \\
(.098)\end{array}$ & $\begin{array}{l}0.168^{*} \\
(.099)\end{array}$ & $\begin{array}{l}0.194 \\
(.184)\end{array}$ & $\begin{array}{l}0.428 \\
(.347)\end{array}$ & $\begin{array}{c}0.236^{*+* *} \\
(.053)\end{array}$ & $\begin{array}{l}0.192 \\
(.382)\end{array}$ \\
\hline Satisfaction ladder: 2010 & $\begin{array}{l}0.277 \\
(.254)\end{array}$ & $\begin{array}{l}0.246^{*} \\
(.146)\end{array}$ & $\begin{array}{l}0.031 \\
(.398)\end{array}$ & $\begin{array}{l}0.264 \\
(.172)\end{array}$ & $\begin{array}{l}0.248 \\
(.192)\end{array}$ & $\begin{array}{l}0.016 \\
(.354)\end{array}$ & $\begin{array}{l}0.431 \\
(.592)\end{array}$ & $\begin{array}{c}0.239^{*+* * *} \\
(.076)\end{array}$ & $\begin{array}{l}0.192 \\
(.653)\end{array}$ \\
\hline \multicolumn{10}{|c|}{ Panel D: International Social Survey Program } \\
\hline Happiness 2008 & $\begin{array}{l}1.03^{* * * *} \\
(.251)\end{array}$ & $\begin{array}{r}-0.087 \\
(.130)\end{array}$ & $\begin{array}{l}1.12^{* * * *} \\
(.320)\end{array}$ & $\begin{array}{l}0.248^{*} \\
(.148)\end{array}$ & $\begin{array}{l}-0.343 \\
(.249)\end{array}$ & $\begin{array}{l}0.592 \\
(.379)\end{array}$ & $\begin{array}{l}1.00^{* * * *} \\
(.243)\end{array}$ & $\begin{array}{l}-0.096 \\
(.132)\end{array}$ & $\begin{array}{l}1.10^{*+* *} \\
(.315)\end{array}$ \\
\hline Happiness 2007 & $\begin{array}{l}0.943^{*+* *} \\
(.208)\end{array}$ & $\begin{array}{c}-0.166^{*+*+} \\
(.064)\end{array}$ & $\begin{array}{l}1.11^{*+* *+} \\
(.240)\end{array}$ & $\begin{array}{l}0.198^{*} \\
(.110)\end{array}$ & $\begin{array}{c}-0.413^{* * *} \\
(.165)\end{array}$ & $\begin{array}{l}0.611^{* * *} \\
(.269)\end{array}$ & $\begin{array}{l}0.942^{* * * *} \\
(.208)\end{array}$ & $\begin{array}{c}-0.167^{* *} \\
(.064)\end{array}$ & $\begin{array}{l}1.11^{* * * *} \\
(.240)\end{array}$ \\
\hline Happiness 2001 & $\begin{array}{l}1.05^{* *} \\
(.408)\end{array}$ & $\begin{array}{l}0.039 \\
(.179)\end{array}$ & $\begin{array}{l}1.01^{* *} \\
(.490)\end{array}$ & $\begin{array}{l}0.391 \\
(.231)\end{array}$ & $\begin{array}{c}-0.484^{*} \\
(.271)\end{array}$ & $\begin{array}{l}0.874^{*} \\
(.500)\end{array}$ & $\begin{array}{l}1.07^{* *} \\
(.426)\end{array}$ & $\begin{array}{l}0.048 \\
(.179)\end{array}$ & $\begin{array}{l}1.02^{* *} \\
(.508)\end{array}$ \\
\hline Happiness 1998 & $\begin{array}{l}1.03^{*+* *} \\
(.365)\end{array}$ & $\begin{array}{l}0.210 \\
(.225)\end{array}$ & $\begin{array}{l}0.817 \\
(.531)\end{array}$ & $\begin{array}{c}0.684^{*+* * *} \\
(.106)\end{array}$ & $\begin{array}{c}-0.676^{*+* *} \\
(.142)\end{array}$ & $\begin{array}{l}1.36^{*+* *+} \\
(.239)\end{array}$ & $\begin{array}{l}1.05^{* *} \\
(.470)\end{array}$ & $\begin{array}{l}0.268 \\
(.217)\end{array}$ & $\begin{array}{l}0.782 \\
(.624)\end{array}$ \\
\hline Happiness 1991 & $\begin{array}{l}0.806^{*} \\
(.447)\end{array}$ & $\begin{array}{l}0.038 \\
(.188)\end{array}$ & $\begin{array}{l}0.768 \\
(.591)\end{array}$ & $\begin{array}{c}0.572^{* * *} \\
(.013)\end{array}$ & $\begin{array}{c}-0.513^{* * *} \\
(.125)\end{array}$ & $\begin{array}{l}1.09^{* * *} \\
(.247)\end{array}$ & $\begin{array}{l}0.960 \\
(.797)\end{array}$ & $\begin{array}{l}0.155 \\
(.176)\end{array}$ & $\begin{array}{l}0.805 \\
(.901)\end{array}$ \\
\hline
\end{tabular}

Notes: ${ }^{* * *},{ }^{* *}$, and ${ }^{*}$ denote statistically significantly different from zero at $1 \%, 5 \%$ and $10 \%$ levels, respectively. 


\section{Within-Country Cross-Sectional Comparisons}

We now turn to analyzing the relationship between well-being and income that one obtains when comparing rich and poor people within a country. We begin by analyzing data from the United States, and in particular, the Gallup poll conducted on December 6-9, 2007. These data are particularly useful because the top income code is unusually high, allowing respondents to report household income in categories up to $\$ 500,000$. If we are to find evidence of satiation, these data seem like the right place to look. Table 3 shows a simple cross-tab of happiness and household income in Panel A, and a cross-tab of life satisfaction and income in Panel B. The positive association between family income and reported well-being is remarkably consistent and shows no signs of petering out even at very high incomes. ${ }^{12}$

Table 3- Income and Satisfaction in the United States

Panel A: Happiness

\begin{tabular}{|c|c|c|c|c|c|c|c|c|}
\hline $\begin{array}{l}\text { Annual Household } \\
\text { Income } \\
\end{array}$ & $\begin{array}{l}\text { Very } \\
\text { Happy }\end{array}$ & $\begin{array}{l}\text { Fairly } \\
\text { Happy }\end{array}$ & $\begin{array}{c}\text { Not Too } \\
\text { Happy }\end{array}$ & $\begin{array}{c}\text { Very } \\
\text { satisfied }\end{array}$ & $\begin{array}{c}\text { Somewhat } \\
\text { satisfied }\end{array}$ & $\begin{array}{l}\text { Somewhat } \\
\text { dissatisfied }\end{array}$ & $\begin{array}{c}\text { Very } \\
\text { dissatisfied }\end{array}$ & $\begin{array}{c}\text { Sample } \\
\text { Size }\end{array}$ \\
\hline$<\$ 10 k$ & $35 \%$ & $44 \%$ & $21 \%$ & $24 \%$ & $19 \%$ & $25 \%$ & $32 \%$ & 24 \\
\hline \$10k-\$20k & $42 \%$ & $42 \%$ & $15 \%$ & $47 \%$ & $23 \%$ & $19 \%$ & $11 \%$ & 78 \\
\hline \$20k-\$30k & $43 \%$ & $52 \%$ & $5 \%$ & $45 \%$ & $30 \%$ & $21 \%$ & $4 \%$ & 107 \\
\hline \$30k-\$40k & $55 \%$ & $41 \%$ & $4 \%$ & $57 \%$ & $28 \%$ & $11 \%$ & $4 \%$ & 106 \\
\hline$\$ 40 k-\$ 50 k$ & $46 \%$ & $46 \%$ & $9 \%$ & $49 \%$ & $33 \%$ & $10 \%$ & $8 \%$ & 100 \\
\hline \$50k-\$75k & $55 \%$ & $40 \%$ & $5 \%$ & $64 \%$ & $26 \%$ & $5 \%$ & $5 \%$ & 162 \\
\hline$\$ 75 k-\$ 100 k$ & $60 \%$ & $36 \%$ & $4 \%$ & $69 \%$ & $27 \%$ & $3 \%$ & $1 \%$ & 107 \\
\hline \$100k-\$150k & $60 \%$ & $40 \%$ & $0 \%$ & $72 \%$ & $26 \%$ & $2 \%$ & $0 \%$ & 118 \\
\hline \$150k-\$250k & $70 \%$ & $30 \%$ & $0 \%$ & $90 \%$ & $7 \%$ & $3 \%$ & $0 \%$ & 57 \\
\hline \$250k-\$500k & $83 \%$ & $17 \%$ & $0 \%$ & $93 \%$ & $7 \%$ & $0 \%$ & $0 \%$ & 15 \\
\hline$>\$ 500 \mathrm{k}$ & $100 \%$ & $0 \%$ & $0 \%$ & $100 \%$ & $0 \%$ & $0 \%$ & $0 \%$ & 8 \\
\hline Whole Sample & $53 \%$ & $41 \%$ & $6 \%$ & $60 \%$ & $26 \%$ & $10 \%$ & $5 \%$ & 1,014 \\
\hline
\end{tabular}

Notes: Author’s calculations, based on Gallup Poll conducted December 6-9, 2007.

\footnotetext{
12 While 100 percent of those reporting annual incomes over $\$ 500,000$ are in the top bucket of "very happy", there are only 8 individuals in this category.
} 
When we analyze these data more formally in regressions we find no evidence of a significant break in either the happiness-income relationship, nor in the life satisfactionincome relationship, even at annual incomes up to half a million dollars. This finding contrasts with a claim made by Frey and Stutzer (2002, p.409) whose informal visual assessment of data from the General Social Survey (for 1972-74 and 1994-96) led them to conclude that "the same proportional increase in income yields a lower increase in happiness at higher income levels.” In our re-analysis of that same dataset, shown in Appendix Figure A5, we could not reject the null that proportional increases in income continue to yield the same increase in happiness at higher income levels.

Looking beyond the United States, we can use the individual country data in the Gallup World Poll to examine the within-country well-being-happiness gradients in each nation. In Figure 2 we perform separate local linear (“lowess”) regressions estimating the satisfactionincome relationship non-parametrically for each of the world's 25 most populous countries. These results are shown for those respondents whose annual household income lies between the $10^{\text {th }}$ and $90^{\text {th }}$ percentiles of their national income distributions. While there are differences in the location of these non-parametric fits, and even some differences in the slopes, the more remarkable feature is simply that for every country the relationship estimated at low incomes appears to hold in roughly equal measure at higher incomes. In particular, there is no evidence that the slope flattens out beyond any particular "satiation point" in any nation. 
Figure 2: Well-Being and Income within the 25 Most Populous Countries

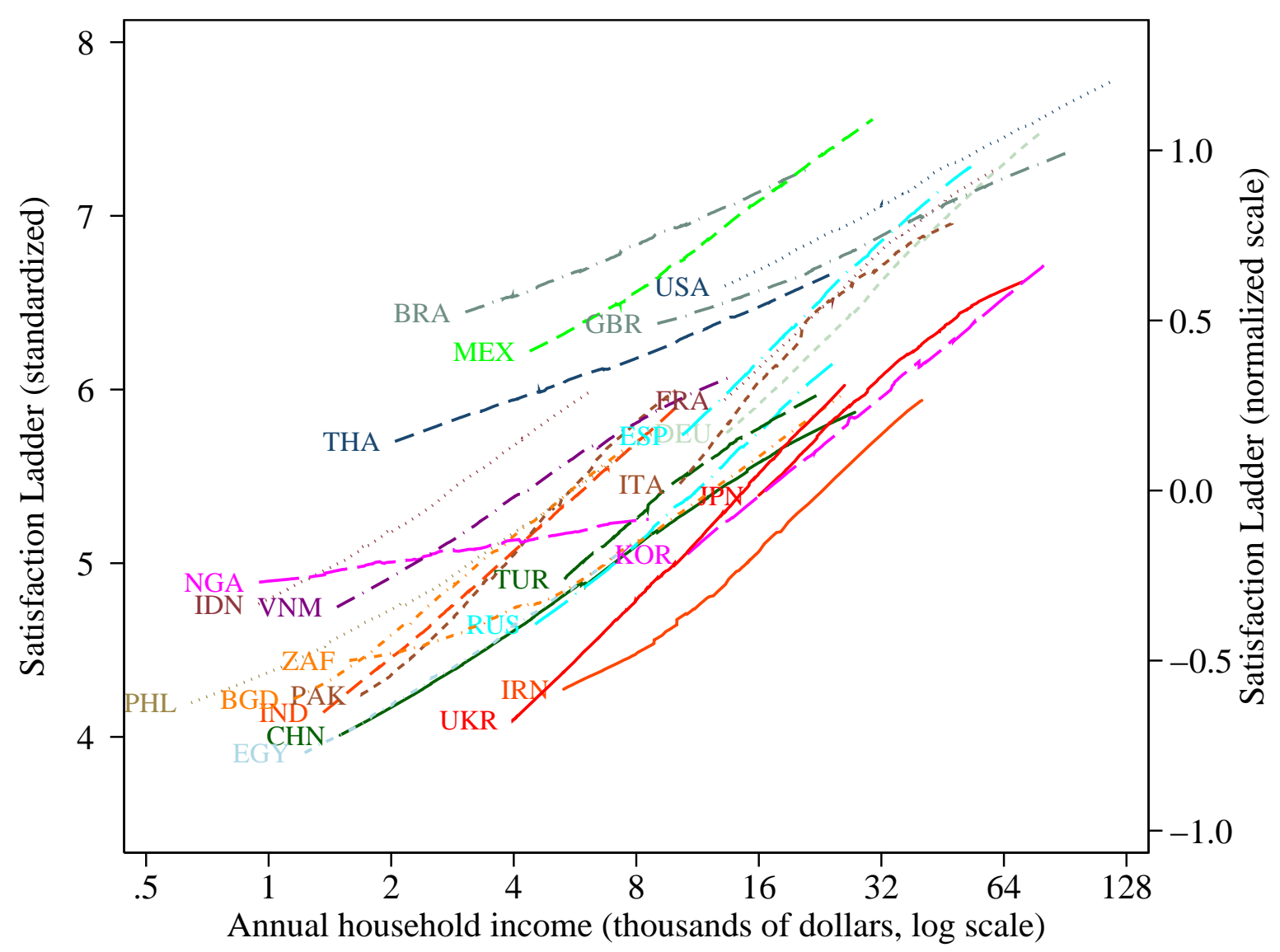

In order to provide a more formal assessment, we repeat the earlier exercise, estimating an analog to equation (2), but analyzing individual well-being and household income, rather than national averages, and allowing the slope to change for household incomes above \$15,000 per annum. We repeat this exercise for 98 countries in which we have at least 200 respondents both above and below the threshold. We report the results of these 98 regressions compactly in Figure 3. The vertical axis shows $\beta_{\text {rich }}$, the estimated well-being-income gradient over the "rich" part of the sample, while the horizontal axis shows $\beta_{\text {poor }}$, the gradient over the "poor" part of the sample. The strong form of modified-Easterlin hypothesis suggests that the well-being-income gradient is zero for the rich part of the sample, suggesting that the data should cluster along the 
horizontal axis. The weaker form of this hypothesis suggests a sharp break in this gradient among the "rich," and hence that most country-level estimates will lie beneath the 45-degree line. In fact, we find 61 nations above this line, and only 37 below.

Figure 3. The Well-Being-Income Relationship Among the Rich and Poor in Each Country

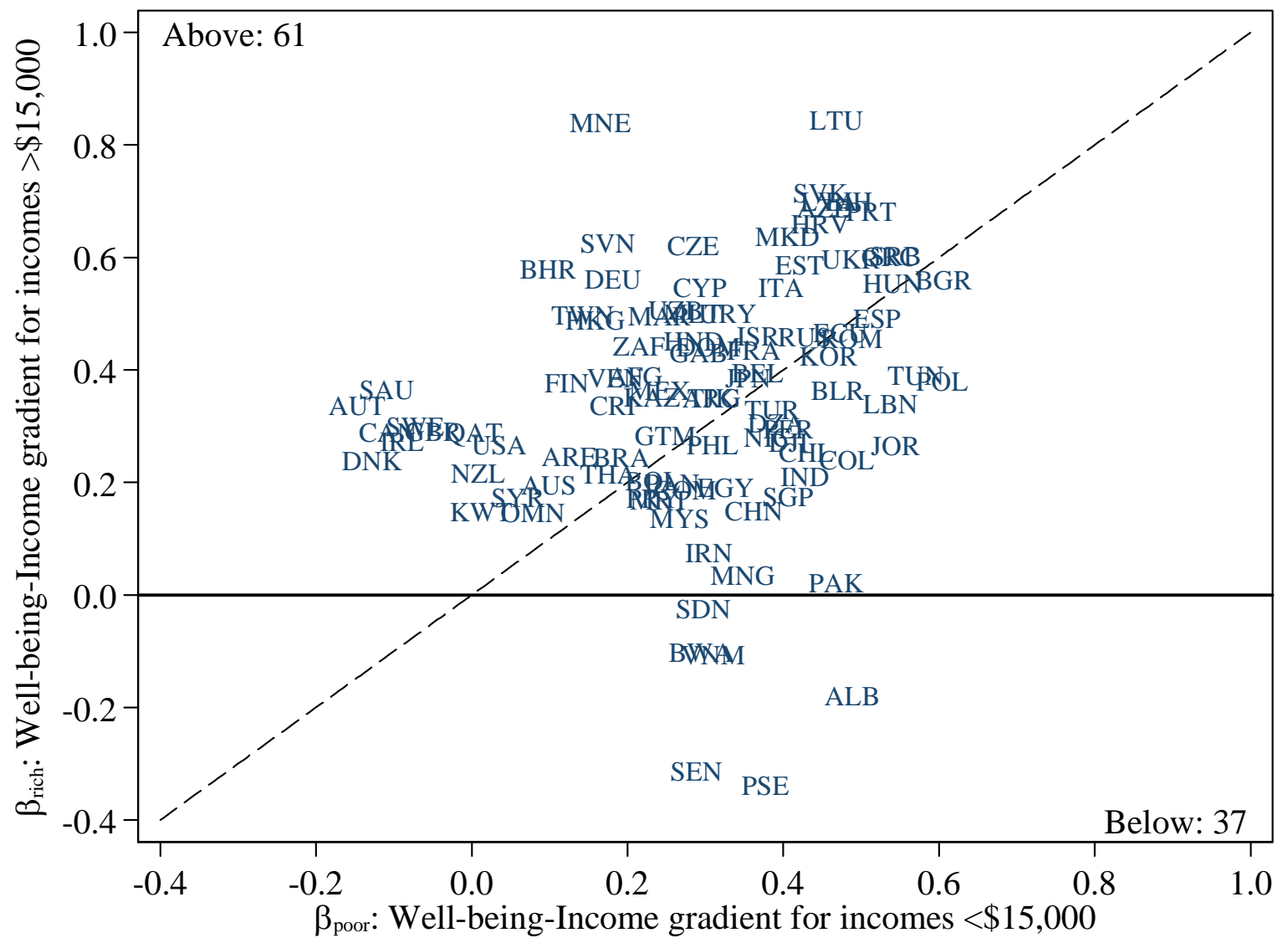

We also try various alternative specifications, changing the cutoff level of $k$ across countries (using alternative cutoffs at at $\$ 8,000$ and $\$ 25,000$ ); in others, $k$ depends on parameters of a country's income distribution-it's median, 25th or 75th percentile. In no case do we find evidence in favor of the modified-Easterlin hypothesis. This analysis is shown in Appendix Figure A6. 


\section{Conclusions}

While the idea that there is some critical level of income beyond which income no longer impacts well-being is intuitively appealing, it is at odds with the data. As we have shown, there is no major well-being dataset that supports this commonly made claim. To be clear, our analysis in this paper has been confined to the sorts of evaluative measures of life satisfaction and happiness that have been the focus of proponents of the (modified) Easterlin hypothesis. In an interesting recent contribution, Kahneman and Deaton (2010) have shown that in the United States, people earning above $\$ 75,000$ do not appear to enjoy either more positive affect nor less negative affect than those earning just below that. We are intrigued by these findings, although we conclude by noting that they are based on very different measures of well-being, and so they are not necessarily in tension with our results. Indeed, those authors also find no satiation point for evaluative measures of well-being. 


\section{References}

Clark, Andrew E., Paul Frijters, and Michael A. Shields. "Relative Income, Happiness and Utility: An Explanation for the Easterlin Paradox and Other Puzzles." Journal of Economic Literature 46, no. 1 (2008): 95-144.

Deaton, Angus "Income, Health, and Well-Being around the World: Evidence from the Gallup World Poll." Journal of Economic Perspectives, 2008 22(2), pp. 53-72.

Di Tella, Rafael, and Robert MacCulloch. Happiness Adaptation to Income beyond "Basic Needs". NBER Working Paper, National Bureau of Economic Research, 2008.

Diener, Ed, and Martin E.P. Seligman. "Beyond money: Toward an economy of well-being." Psychological Science in the Public Interest 5 (2004): 1-31.

Easterlin, Richard A. "Does economic growth improve the human lot? Some empirical evidence." In Nations and Households in Economic Growth: Essays in Honor of Moses Abramowitz, by Paul A David and Melvin W. Reder. New York: Academic Press, Inc., 1974.

Easterlin, Richard A., and Onnicha Sawangfa. Happiness and Economic Growth: Does the Cross Section Predict Time Trends? Evidence from Developing Countries. mimeo, University of Southern California, 2009.

Frey, Bruno S., and Alois Stutzer. "What Can Economists Learn from Happiness Research?" Journal of Economic Literature 40 (2002): 402-435.

Kahneman, Daniel and Angus Deaton. "High Income Improves Evaluation of Life But Not Emotional Well-Being” Proceedings of the National Academy of Sciences, September 72010 , 107(38) 16489-16493.

Layard, Richard. "Happiness: Has Social Science a Clue." Lionel Robbins Memorial Lectures 2002/3. London School of Economics, 2003.

—. Happiness: Lessons from a New Science. London: Penguin, 2005.

Oswald, Andrew J. "On the Curvature of the Reporting Function from Objective Reality to Subjective Feelings." Economics Letters, 2008.

Sacks, Daniel, Betsey Stevenson, and Justin Wolfers "The New Stylized Facts About Income and Subjective Well-being”, Emotion, Dec 2012, 12 (6): 1181-1187

Sacks, Daniel, Betsey Stevenson, and Justin Wolfers "Growth in Subjective Well-being and Income over Time”, 2013 mimeo.

Stevenson, Betsey, and Justin Wolfers. "Economic Growth and Happiness: Reassessing the Easterlin Paradox." Brookings Papers on Economic Activity, Spring 2008: 1-87 


\section{Appendix}

Figure A1: World Value Survey - Satisfaction, 1989-2008

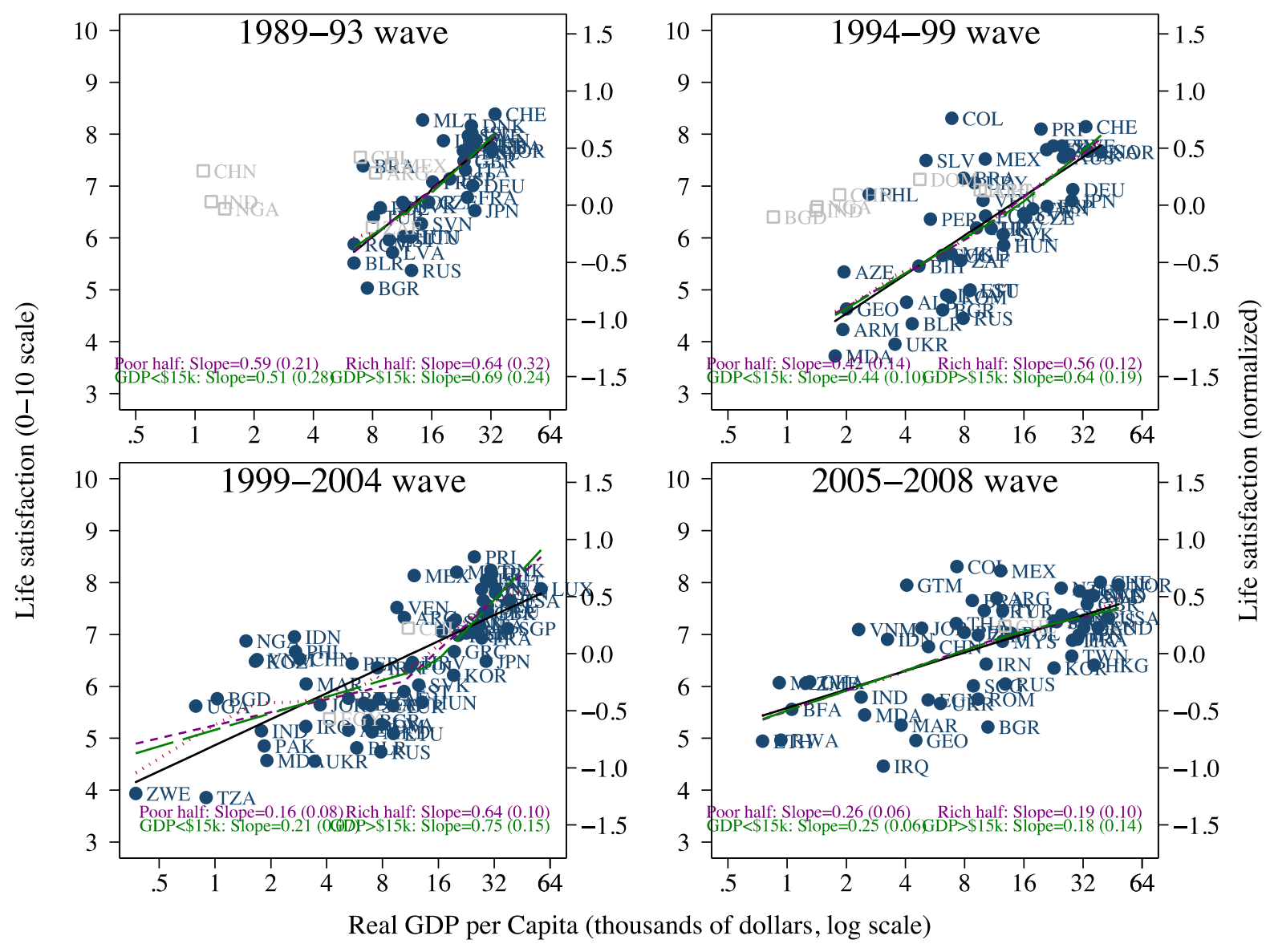


Figure A2: World Value Survey -Happiness, 1989-2008

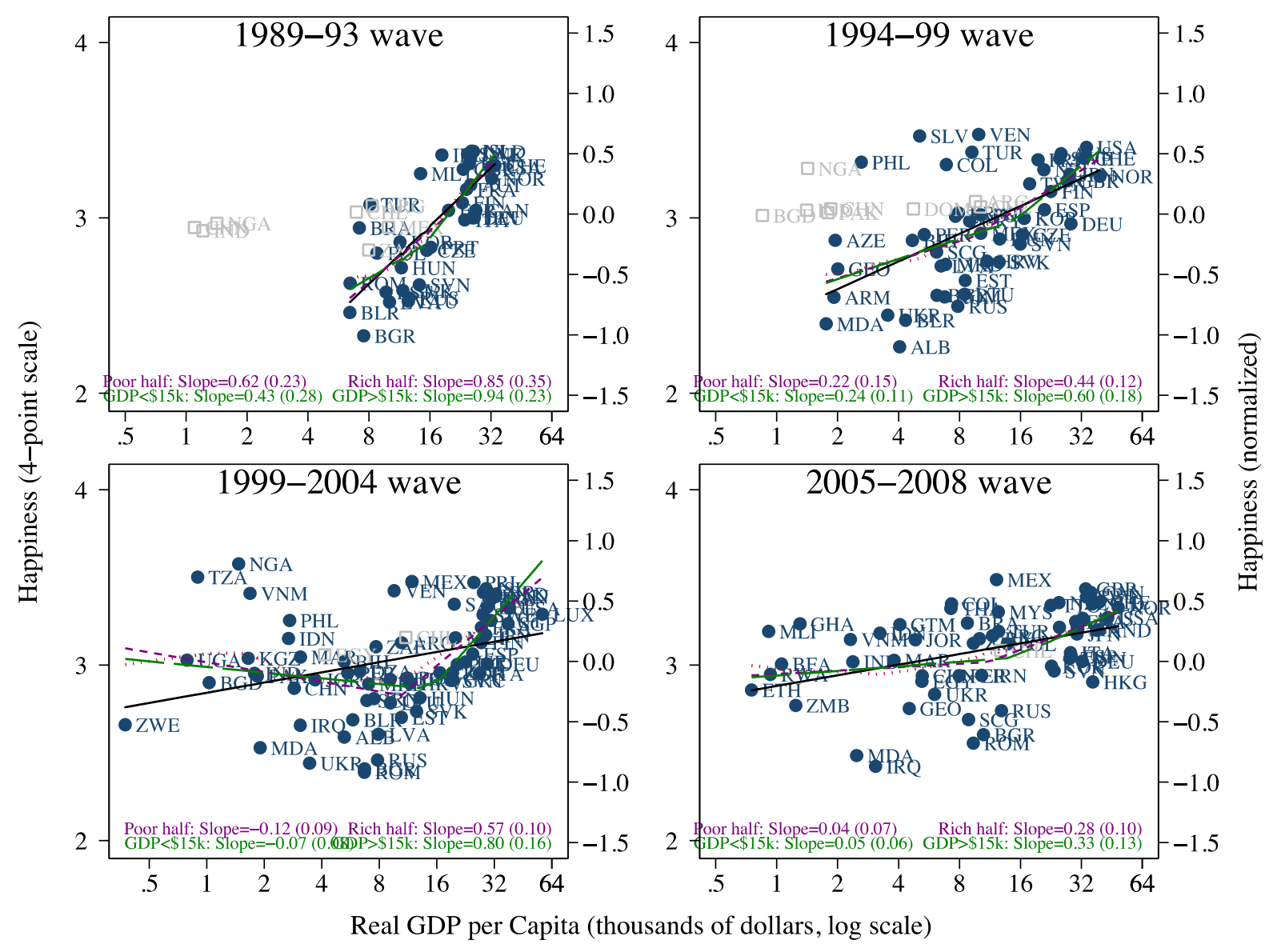


Figure A3: Pew Satisfaction, 2002-2010

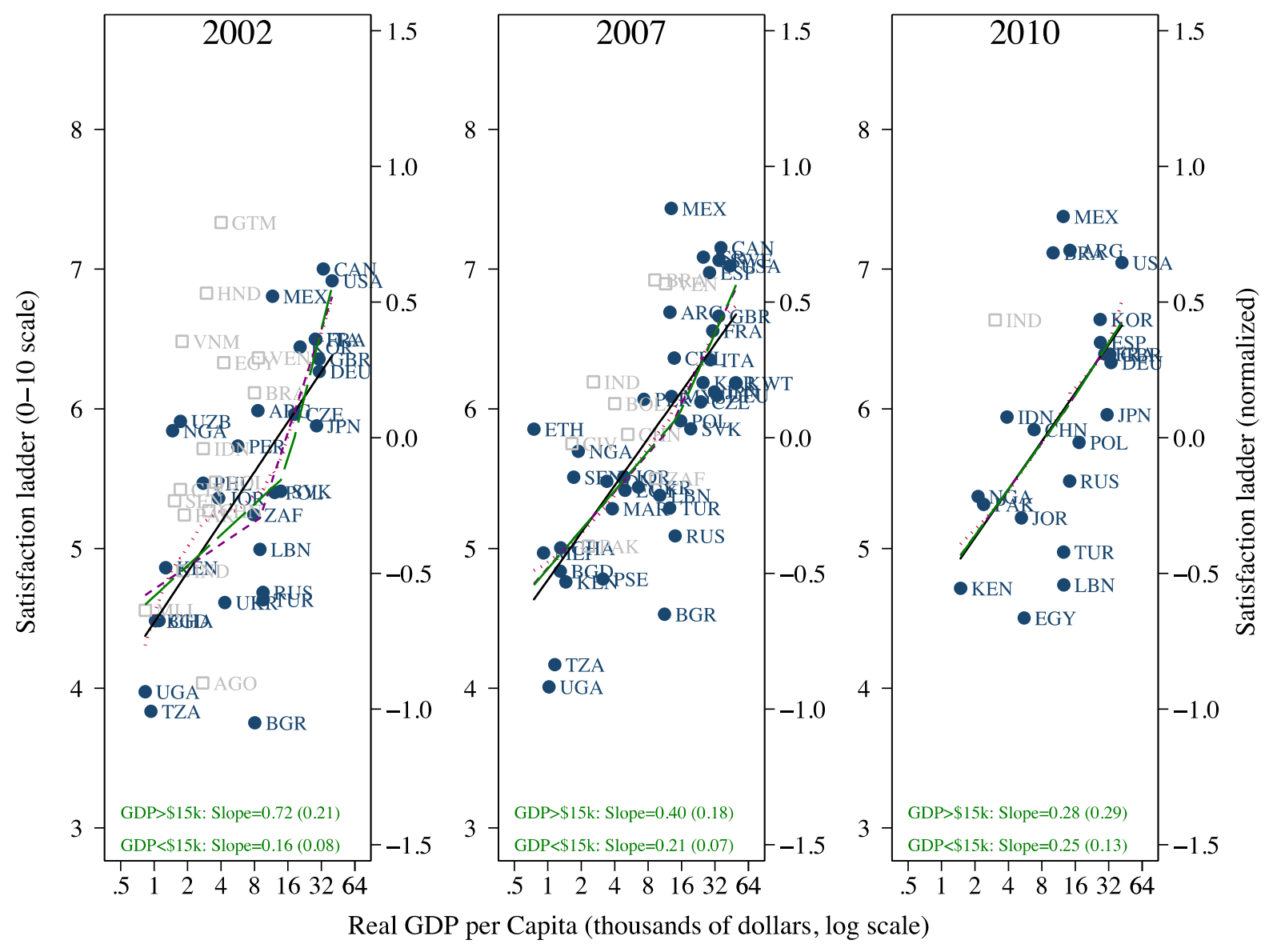


Figure A4: ISSP Happiness, 1991-2008

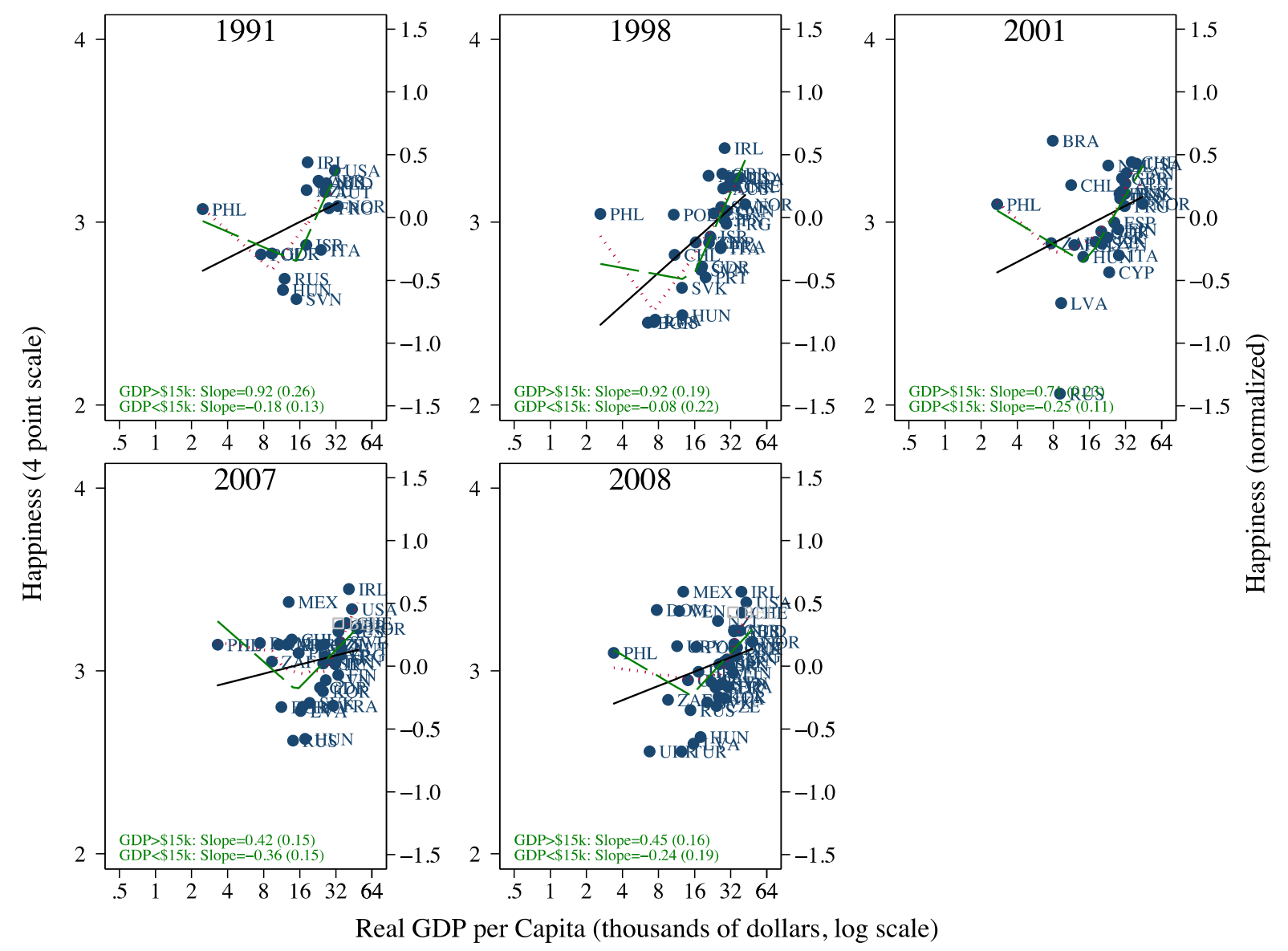


Figure A5: Subjective Well-being and Income in the General Social Survey

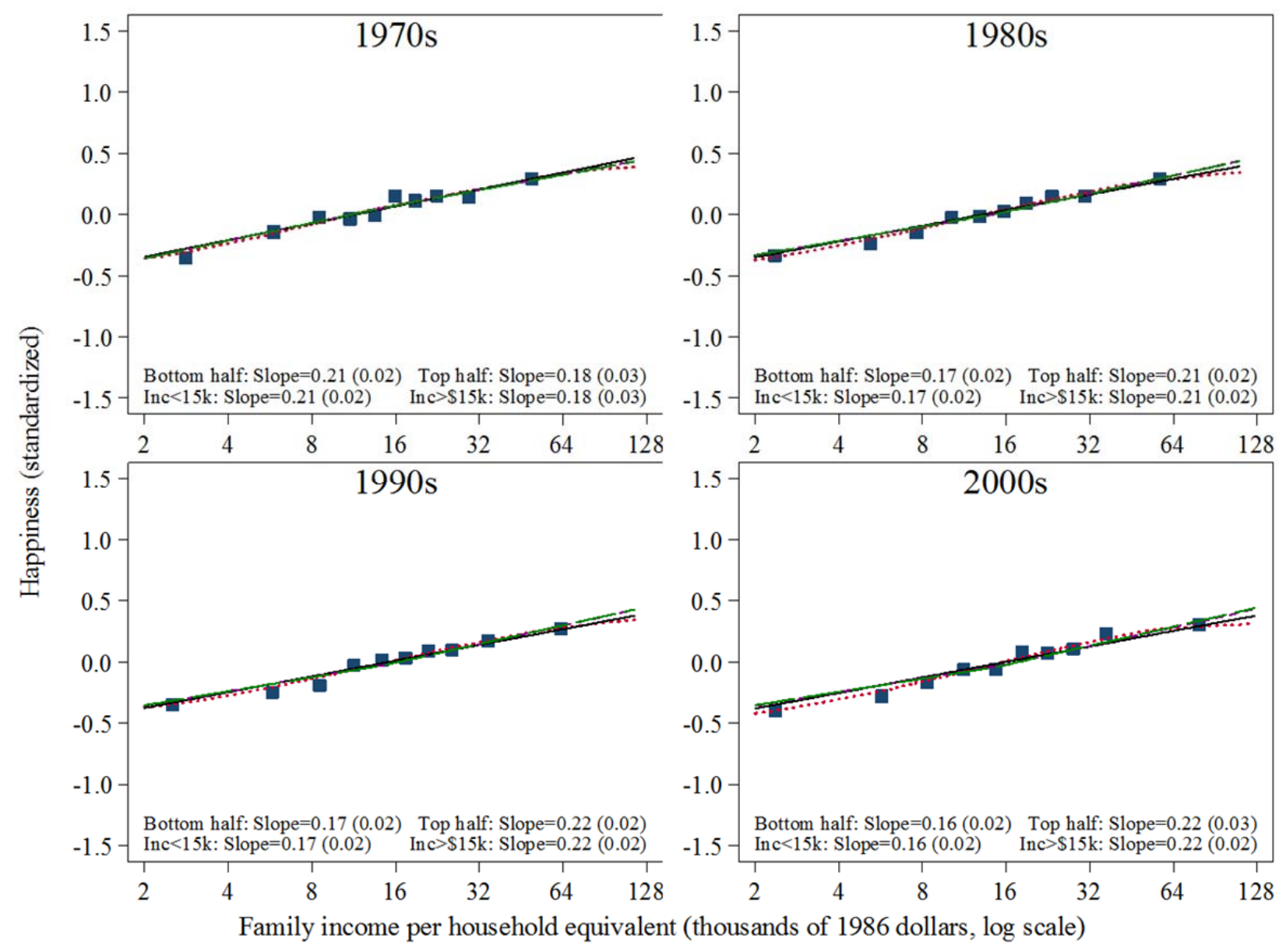


Figure A6: Well-being-Income Gradient
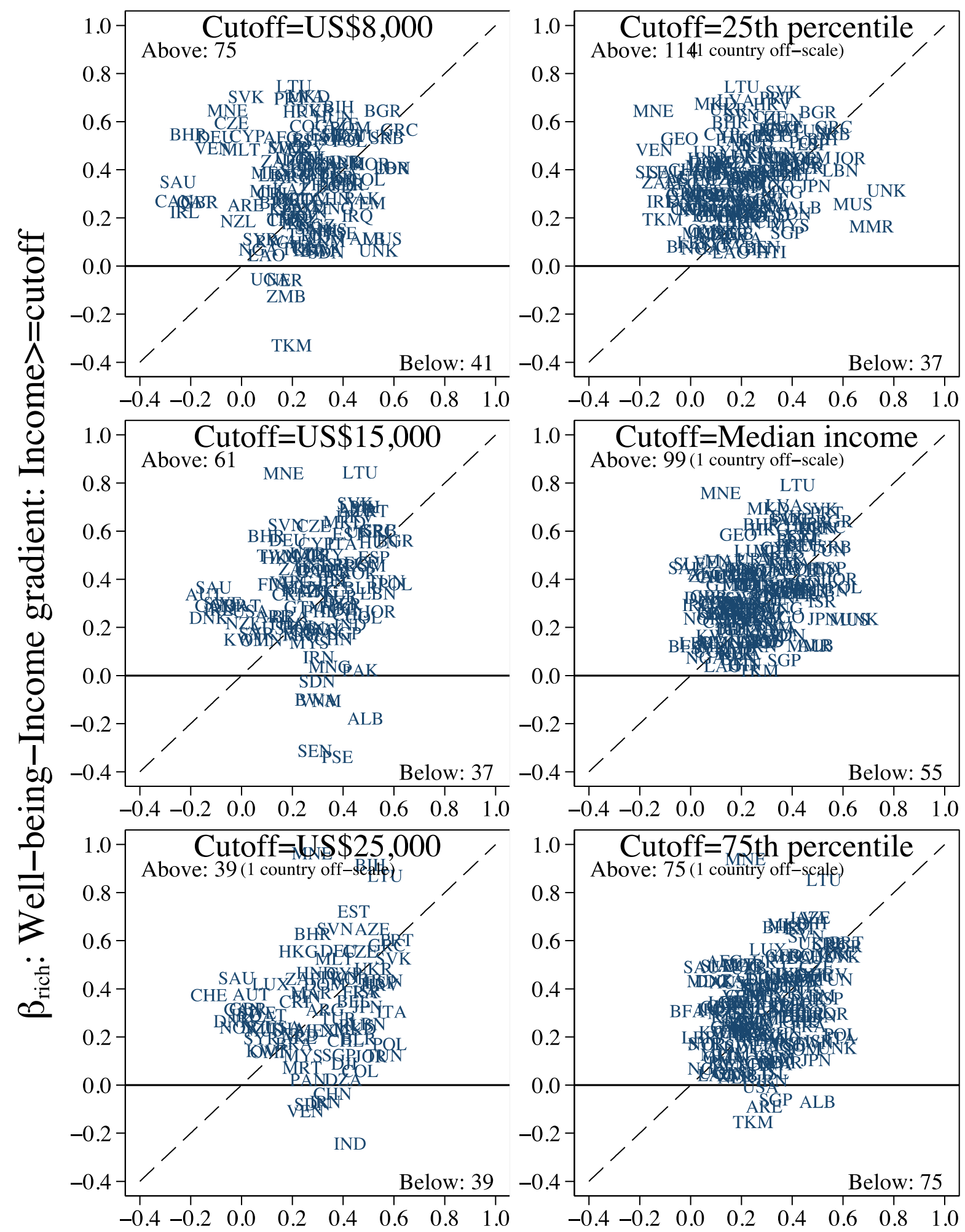

$\beta_{\text {poor }}$ : Wellbeing-Income gradient: Income $<$ cutoff 